\title{
Abortive diseases and their various associated risk factors in small ruminants in Algeria: a systematic review
}

\author{
Asma Haif $^{1} \cdot$ Nadjet Amina Khelifi-Ouchene ${ }^{2,3} \cdot$ Manal Khelifi $^{4} \cdot$ Imane Ouchetati $^{5} \cdot$ Fayçal Zeroual $^{1}$. \\ Nassim Ouchene ${ }^{2,3}$
}

Received: 15 January 2021 / Accepted: 10 September 2021 / Published online: 20 October 2021

(c) The Author(s), under exclusive licence to Springer Nature B.V. 2021

\begin{abstract}
Abortive infections are a major health challenge affecting productive and reproductive performance of sheep and goats. However, there is no comprehensive summary on the occurrence and distribution of these infections in Algeria. This systematic review provides a comprehensive summary on the prevalence of different abortive diseases and assesses potential risk factors in small ruminants in Algeria. Five databases were used to search epidemiological data on the prevalence of different abortive diseases (bacterial, parasitic, and viral). Data were collected from 25 papers published between 2003 and 2020. The total mean sample size was 53,080 small ruminants. The majority of the diseases/infections were diagnosed by serological and molecular tests. The overall prevalence of brucellosis was $0.39 \%$ in sheep and $5.31 \%$ in goats. Chlamydia and Q fever were observed in $32.72 \%$ and $20.62 \%$ of small ruminants, respectively. The prevalence of peste des petits ruminants was $15.76 \%$ and the overall prevalence of bluetongue in sheep and goats was, respectively, $13.41 \%$ and $44.50 \%$. Border disease and bovine viral diarrhea were detected in $22.68 \%$ and $1.01 \%$ of sheep examined, respectively. Toxoplasma gondii infection prevalence among sheep and goats was $21.43 \%$ and $32.31 \%$ respectively. This study is a comprehensive epidemiological analysis of abortion diseases in small ruminants in Algeria and will therefore be a useful tool for researchers. Larger and more robust prevalence studies are needed to adequately support risk assessment and management of animal and public health threats.
\end{abstract}

Keywords Algeria $\cdot$ Abortive diseases $\cdot$ Goats $\cdot$ Sheep $\cdot$ Prevalence $\cdot$ Systematic review

\section{Introduction}

Abortion in small ruminants is one of the major problems that can cause considerable economic losses due to the death of fetuses and reduced milk production and it may occur sporadically or as enzootic outbreaks. The etiology may be infectious or non-infectious (Vidić et al. 2007; Entrican

Nadjet Amina Khelifi-Ouchene

khelifinaa@gmail.com

1 Department of Veterinary Sciences, University of El Tarf, 36000 El Tarf, Algeria

2 Institute of Veterinary Sciences, University Saad Dahlab of Blida 1, Street Soumaa, BP270, 09000 Blida, Algeria

3 Laboratory PADESCA, Veterinary Sciences Institute, Road of Guelma, El-khroub, 25100 Constantine, Algeria

4 Bordj Menaiel Hospital, Street Madaoui Ali, BP70, 35000 Boumerdes, Algeria

5 Normal High School of Technological Teaching, University of Skikda, 21000 Skikda, Algeria et al. 2009). Infectious abortions are the most common and are caused by bacteria (Chlamydia abortus, Campylobacter spp., Listeria spp., Coxiella burnetii, Brucella melitensis), virus (bluetongue virus; plague of small ruminants virus, border disease virus), and parasites (Toxoplasma gondii) (Celli and Gorvel 2004; Khan et al. 2011; Kaufmann et al. 2012; Martin et al. 2015; Tegegne et al. 2016; Elhaig et al. 2018; Tejedor-Junco et al. 2019). Abortions are also caused by non-infectious etiologies such as toxicities, genetic factors, metabolic and nutritional problems, and physical factors (Vidić et al. 2007).

The breeding of small ruminants is a primordial activity of the North African breeder (Rondia 2006) and is the main source of red meat in Algeria (Mebirouk-Boudechiche et al. 2014). Small ruminants are farmed under the traditional extensive system in Algeria, and intensive farming systems have recently been introduced in the country. The total number of sheep and goats in Algeria has been estimated in 2017 at 26.4 million and 4.8 million heads, respectively, which constitutes an important wealth for the country (MADR 
2018) and contribute substantially to food security, to the economy of mountain households, to their maintenance in poor and inaccessible territories, and require a human presence in regions exposed to rural exodus (Ouchene-Khelifi et al. 2015; 2018). However, the breeding of small ruminants in Algeria is subject to several constraints, including abortions. Khaled and Bouyoucef (2013) have reported that $90 \%$ of Algerian farmers had observed abortions on their farms.

Therefore, a comprehensive overview of abortive diseases in small ruminants has become crucial for the development of effective prevention and control measures and for a better prevention of human contamination since most of these diseases are zoonoses.

A recent systematic review, pertaining to small ruminants diseases (Kardjadj 2017), concluded that the epidemiological status of small ruminant diseases in Algeria is striking and the main infectious diseases threatening its small ruminant industry are peste des petits ruminants, bluetongue, foot and mouth disease, sheep pox/goat pox, brucellosis, and Rift Valley fever.

This systematic review is solely focused on the prevalence of abortion causes in sheep and goats in Algeria and its association with several risk factors.

\section{Material and methods}

\section{Literature search strategy}

This systematic review and meta-analysis was structured according to the recommendations of the Preferred Reporting Elements for Systematic Reviews and Meta-analysis (PRISMA; Moher et al. 2009). The study included only articles published in English that analyzed the causes of abortion infection in small ruminants in Algeria. The search was conducted using five literature databases, including PubMed, Thomson Reuters, ScienceDirect, Scopus, and Google Scholar. The search criteria were specified in advance, and was executed on April 8, 2020, and last updated on July 7, 2020. The following keywords with different combinations were used for the search: "abortion" and "brucellosis" or "Brucella melitensis" or "chlamydiosis" or "Chlamydia abortus" or "Q fever" or "Coxiella burnetii" or "Campylobacteriosis" or "Campylobacter spp" or "salmonellosis" or "Salmonella spp" or "leptospirosis" or "Leptospira spp" or "listeriosis" or "Listeria spp" or "mycoplasmosis" or "Mycoplasma spp" or "pestivirus" or "peste des petits ruminants (PPR)" or "bluetongue virus (BTV)" or "Border disease virus (BDV)" or "Bovine virus diarrhea virus (BVDV)" or "toxoplasmosis" or "Toxoplasma gondii" or "neosporosis" or "Neospora caninum" or "trichomonosis" or "Trichomonas feetus" or "mycosis" or "Aspergillus spp" and "prevalence" or "epidemiology" and "risk factors" and "sheep" or "goat" or "small ruminants" and "Algeria." The collected bibliographic references were screened carefully in order to eliminate duplicates. Also, the reference lists of reviews, and all the retrieved articles, were manually searched during the same period to maximize article recovery.

\section{Eligibility criteria}

An article was included if it fulfilled the following criteria: (1) Full text in the English language published online up to July 2020; (2) descriptive or cross-sectional study (or clarity of objective/s) (estimation of prevalence or otherwise); (3) research reporting the prevalence of different abortion causes in small ruminants and their risk factors using different methods (serological examination, parasite observation, or PCR detection of NA); (4) exact total sample size, positive samples, and the study period were available. Articles were excluded when any of the above criteria were not met. We did not consider redundant articles or data, conference abstracts, and review articles.

All identified studies from the searches were independently assessed for eligibility and inclusion by two different authors. Discrepancies were resolved by discussion and consensus. If required, authors were contacted for clarifying the eligibility of papers.

\section{Data extraction}

A suitable data extraction template was prepared to collect and organize information from each reviewed study. The information retrieved included first author, year of publication, animal species, geographical area of study, sample size (number of examined animals), number of cases, prevalence rate, type of simple, diagnostic tests used for the study, sensitivity and specificity of diagnostic tests, risk factors, and the year in which studies were carried out. If required, authors were contacted for additional information.

\section{Results}

\section{Literature search result}

Through this search, 25 papers published between 2003 and 2020 were identified, eligible to be included in our systematic review and meta-analysis study. The number of articles screened, excluded, and included in the meta-analysis is shown in the diagram (Fig. 1). 
Fig. 1 Flow diagram of the selection of eligible studies

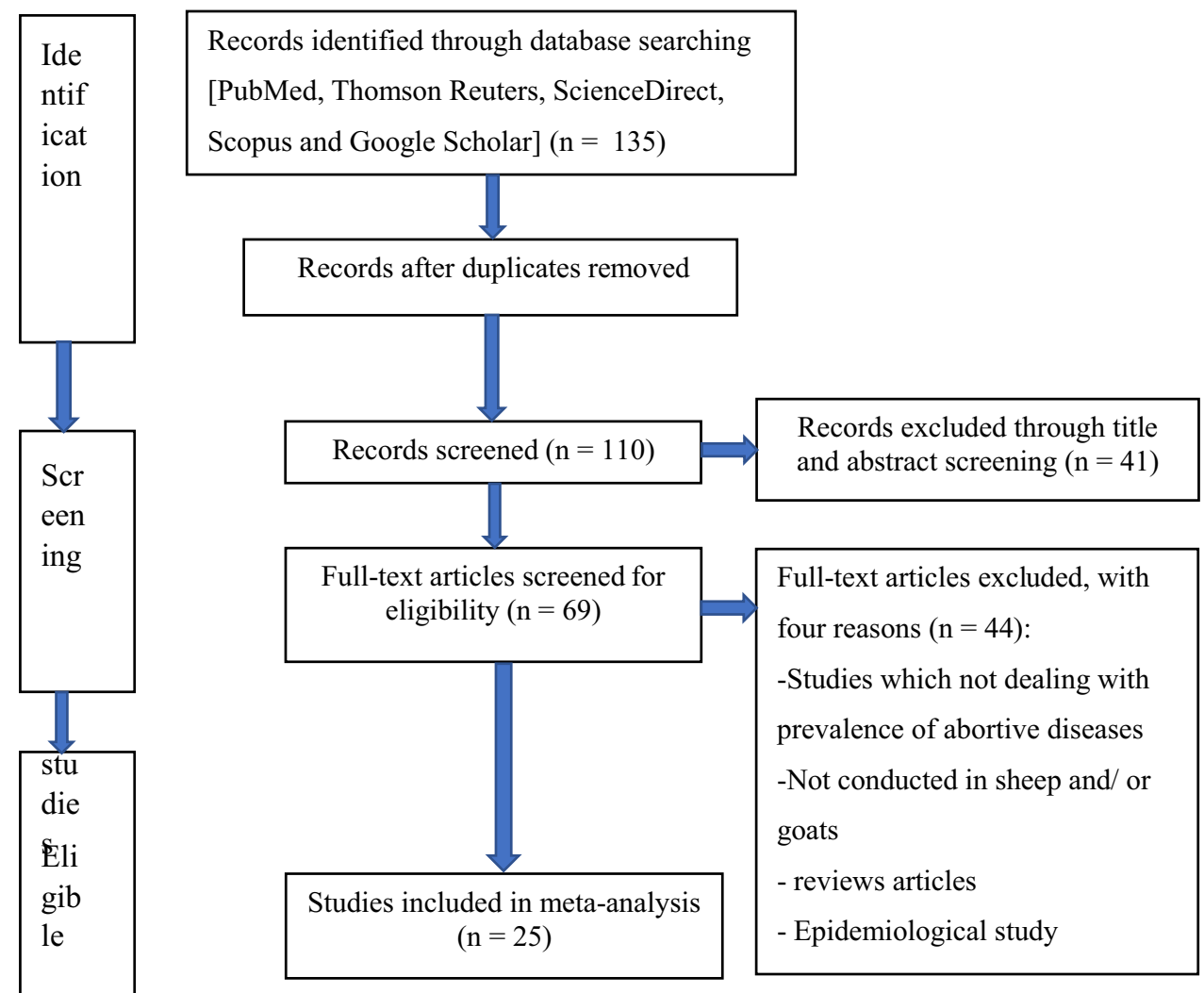

\section{Causes of abortion}

Examination of these 25 studies revealed the existence of 10 different infectious and parasitic abortive diseases of small ruminants in Algeria, including four (4) bacterial diseases (brucellosis, chlamydiosis, Q fever, and salmonellosis), five (5) viral diseases (PPR, bluetongue, border disease, CAE, and BVDV), and one (1) parasitic cause (toxoplasmosis) (Table 1). No eligible studies were conducted on mycosis causes. Among the 25 studies, 3 reported multiple diseases (multiple pathogen survey).

The total number of small ruminants included in these 25 studies was 54,330, of which 5080 (9.35\%) were reported to be diseased and/or infected with one of the 10 reported infectious or parasitic diseases. The majority of diseases/ infections were diagnosed by serological and molecular tests.

\section{Spatial distribution of eligible studies}

Out of the 25 studies, 9 (36\%) were conducted in several regions across the country. Six (24\%) studies were carried out in northeastern Algeria: $2(8 \%)$ studies each in Constantine and Tebessa; 1 (4\%) in Mila; and 1 (4\%) study in the eastern highlands (Batna and Setif).

Five studies (20\%) were conducted in north-central Algeria and the highlands: one study (4\%) each in Djelfa, Tiaret,
Table 1 Diseases categories, number of studies, and sample size of all eligible studies

\begin{tabular}{lll}
\hline Diseases categories & No. of studies (\%) & $\begin{array}{l}\text { Sample size } \\
\text { (sheep and } \\
\text { goats) }\end{array}$ \\
\hline $\begin{array}{l}\text { Bacterial diseases } \\
\text { Brucellosis }\end{array}$ & $06(20)$ & 33,205 \\
Chlamydiosis & $05(16.66)$ & 1809 \\
Q fever & $02(6.66)$ & 674 \\
Salmonellosis & $01(3.33)$ & 43 \\
Viral diseases & & \\
PPR & $04(13.33)$ & 8143 \\
Bluetongue & $03(10)$ & 3022 \\
Border disease & $01(3.33)$ & 2151 \\
CAE & $01(3.33)$ & 105 \\
BVDV & $01(3.33)$ & 197 \\
Parasitic disease & & 4980 \\
Toxoplasmosis & $06(20)$ & 54,330 \\
Total & $25(100)$ &
\end{tabular}

$P P R$ pest des petits ruminants, $C A E$ caprine arthritis encephalitis, $B V D V$ bovine viral diarrhea virus 
and Ksar El-Boukhari; and 2 studies (8\%) were conducted along the highlands of central Algeria.

Two studies (8\%) were carried out in the north-west of the country: one study (4\%) in Mostaganem and the other in Sidi Belaabes.

The other three studies (12\%) were carried out in the south of the country (the Sahara) and were distributed as follows: one study (4\%) in the north of the Sahara (Ghardia) and two studies (8\%) in the south-west of the Sahara (Tindouf and Beni-Abbes).

\section{Distribution of studies over time}

Examining the distribution of published studies over time, it was found that 23 studies (92\%) were conducted and published from 2011 to the present. However, only two studies (8\%) were published before this date.

\section{Determination of abortive diseases}

\section{Bacterial diseases}

A total of 14 papers (Table 2) reported the prevalence of bacterial abortive diseases, and their risk factors in small ruminants included 4 infections: brucellosis, chlamydiosis, $\mathrm{Q}$ fever, and salmonellosis (Tables 1,2). Most of these investigations were serological studies using different laboratory methods (RBPT, BAPAT, CFT, ELISA, PCR, and card test) (Table 2), while no publications have documented the prevalence of campylobacteriosis, leptospirosis, and listeriosis.

Brucella spp. Six papers discussed the prevalence, and the risk factors of brucellosis in small ruminants' flocks. Most of these investigations were based on serological test: 5 studies performing RBPT; 1 study performing BAPAT, 1 study performing card test, and 1 study performing ring test. The total number of individual samples was 7260 sheep and 25,945 goats. The reported prevalence ranged from 0.06 to $2.22 \%$ and from 3.05 to $68.42 \%$ in sheep and goats respectively. The overall estimated prevalence was $0.39 \%(0.23-0.56 \%$; 95\% CI) in sheep $(21 / 5328)$ and $5.31 \%(5.04-5.59 \%$; $95 \%$ CI) in goats $(1354 / 25,456)$.

For the culture and the identification of Brucella spp., twenty-six (68.42\%) bacterial isolations were characterized by Gabli et al. (2015) in goats' vaginal swabs. Only Biovar 3 B. melitensis strains were identified.

Risk factors associated with Brucella spp. seropositivity in small ruminants were identified: age, sex of animal, herd size, management system (nomadic/sedentary systems), gestation rank, and parity (Gabli et al. 2015; Kardjadj et al. 2016a, 2016b; Kouri et al. 2018).
Chlamydia spp. Information on Chlamydia infection in small ruminants was obtained from 5 studies using indirect ELISA, real-time PCR, and PCR-RFLP methods. Analysis included a total of 1809 sheep and goats. The reported seroprevalence ranged from 08.5 to $35.41 \%$. Meta-analysis showed that the prevalence of chlamydiosis in small ruminants was $32.72 \%$ (27.61-37.82\%; 95\% CI). Chlamydia abortus (43.3\%) was the species most frequently detected, followed by C. pecorum (20\%) (Merdja et al. 2015a).

The most potential risk factors associated with chlamydiosis infection in small ruminants were age, reproductive disorders (stillbirth problem, mortality rate in young lambs, and septicemia in lambs), management system (not using disinfectants, availability of veterinary service, and visit of adjacent farm-workers), and the region (Hireche et al. 2014; Hireche et al. 2016; Abdelkadir et al. 2017).

Coxiella burnetii Few studies have targeted Coxiella burnetii infection in small ruminants. A total number of individual samples were 674 sheep and goats. The overall estimated prevalence in small ruminants was 20.62 (17.57-23.68\%; 95\% CI) (139/674). The first report was conducted by Khaled et al. (2016). Indirect ELISA was used to detect specific antibodies against $C$. burnetii, and real-time PCR was used to detect bacterial DNA. The survey indicated that individual seroprevalence was estimated at $14.1 \%$ and $21.3 \%$ of females have proved $C$. burnetii excretion. Abdelkadir et al. (2017) were reported a prevalence of $27.78 \%$ in aborted ewes.

Salmonella spp. There was only one study that treated salmonella infection in goats. Forty-three milk samples were tested using CONDA media for bacterial culture and the results were all negative.

\section{Viral diseases}

Viral causes have been reported in eight papers that have concerned PPRV, BTV,BDV, CAEV and BVDV (Table 3).

Peste des petits ruminants virus (PPRV) Four articles were revealed reporting information on the prevalence of peste des petits ruminants (PPR) in Algeria. Two (2) testing methods were used: c-ELISA and rt-PCR. The total number of investigations performed was 8134 sheep and goats of which 1282 were positive (15.76\%), (14.97-16.55\%; 95\% CI). The prevalence varied from 10.58 to $65.62 \%$.

Age, herd mix, and contact with other herds were the main risk factors identified (Kardjadj et al. 2015b; Baazizi et al. 2017). 


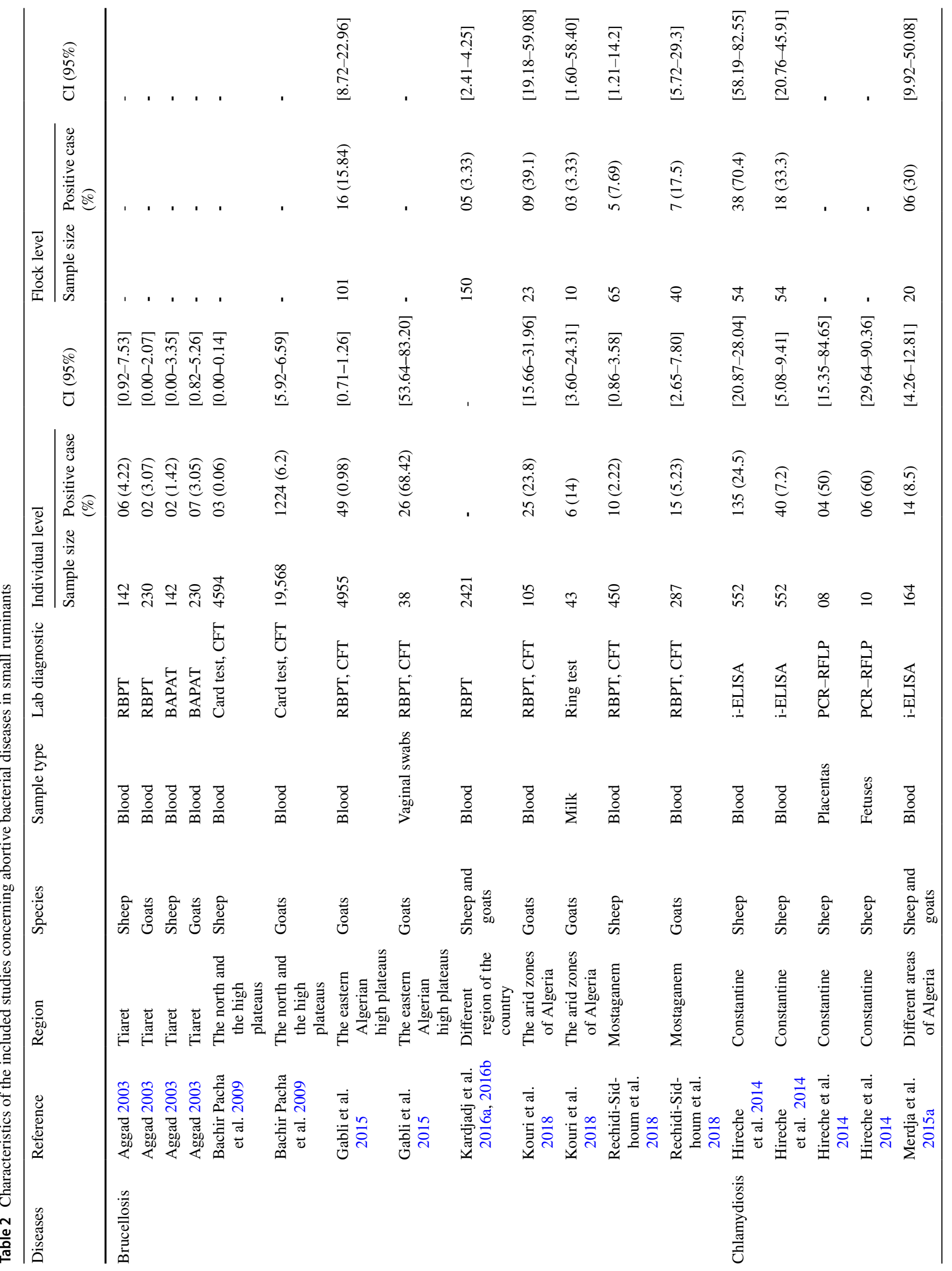




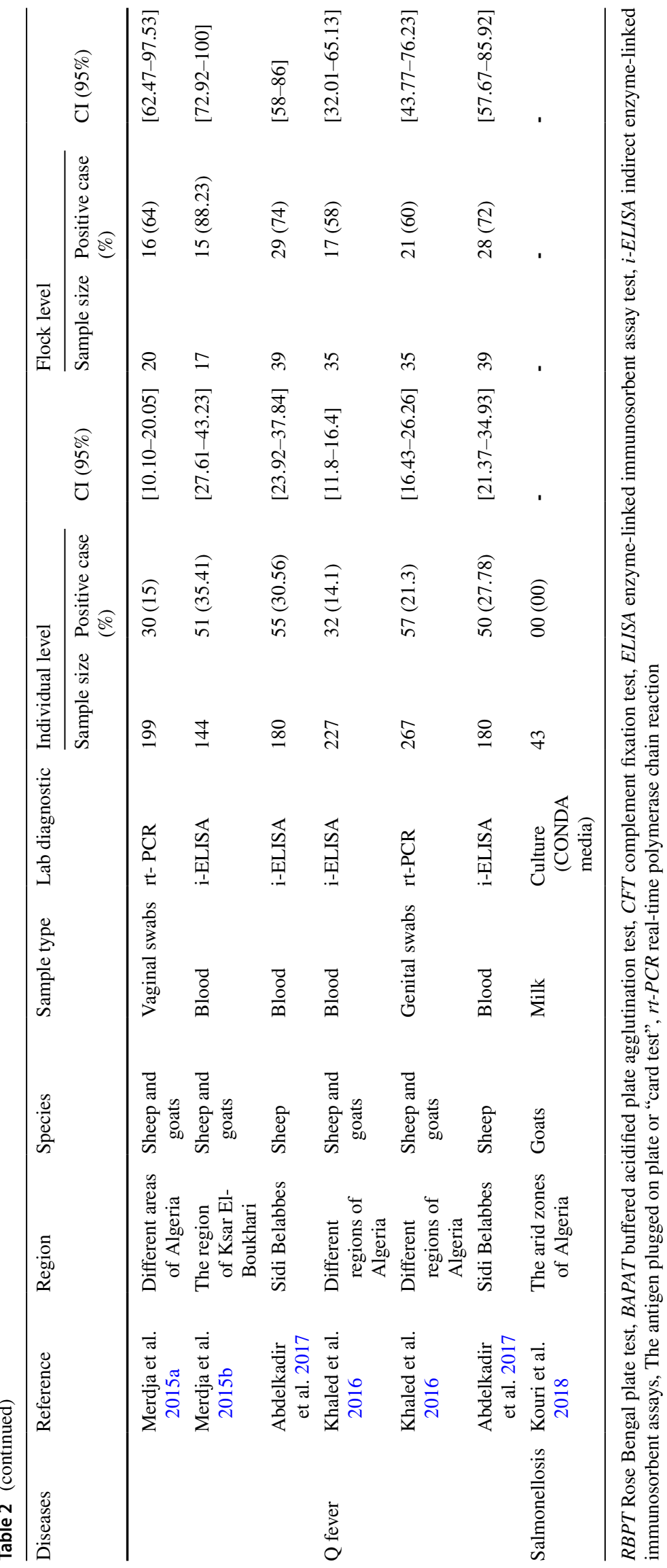


Table 3 Characteristics of the included studies concerning abortive viral diseases in small ruminants

\begin{tabular}{|c|c|c|c|c|c|c|c|c|c|}
\hline \multirow[t]{2}{*}{ Diseases } & \multirow[t]{2}{*}{ Reference } & \multirow[t]{2}{*}{ Region } & \multirow[t]{2}{*}{ Species } & \multirow[t]{2}{*}{ Sample type } & \multirow{2}{*}{$\begin{array}{l}\text { Lab diag- } \\
\text { nostic }\end{array}$} & \multirow[b]{2}{*}{ Sample size } & \multicolumn{2}{|c|}{ Individual level } & \multirow[b]{2}{*}{ CI $(95 \%)$} \\
\hline & & & & & & & Positive case & $\begin{array}{l}\text { Prevalence } \\
\%\end{array}$ & \\
\hline \multirow[t]{11}{*}{ PPRV } & $\begin{array}{l}\text { De Nardi } \\
\text { et al. } 2011\end{array}$ & Tindouf & $\begin{array}{l}\text { Sheep and } \\
\text { goats }\end{array}$ & $\begin{array}{l}\text { Nasal swabs, } \\
\text { ocular } \\
\text { swabs, } \\
\text { whole } \\
\text { blood }\end{array}$ & rt-PCR & 09 & 03 & 33.3 & [2.53-64.13] \\
\hline & $\begin{array}{l}\text { Kardjadj } \\
\text { et al. 2015a }\end{array}$ & Ghardaïa & Sheep & Blood & c-ELISA & 30 & 06 & 20 & [5.69-34.31] \\
\hline & $\begin{array}{l}\text { Kardjadj } \\
\text { et al. 2015a }\end{array}$ & Ghardaïa & Goats & Blood sera & c-ELISA & 32 & 11 & 34.37 & [17.92-50.83] \\
\hline & $\begin{array}{l}\text { Kardjadj } \\
\text { et al. 2015a }\end{array}$ & Ghardaïa & Sheep & Blood & rt-PCR & 30 & 6 & 20 & [5.69-34.31] \\
\hline & $\begin{array}{l}\text { Kardjadj } \\
\quad \text { et al. } 2015 \mathrm{a}\end{array}$ & Ghardaïa & Goats & Blood & rt-PCR & 32 & 8 & 25 & {$[10.00-40.00]$} \\
\hline & $\begin{array}{l}\text { Kardjadj } \\
\text { et al. 2015a }\end{array}$ & Ghardaïa & Sheep & $\begin{array}{l}\text { Oculo-nasal } \\
\text { swabs }\end{array}$ & rt-PCR & 30 & 15 & 50 & [32.11-67.89] \\
\hline & $\begin{array}{l}\text { Kardjadj } \\
\text { et al. 2015a }\end{array}$ & Ghardaïa & Goats & $\begin{array}{l}\text { Oculo-nasal } \\
\text { swabs }\end{array}$ & rt-PCR & 32 & 21 & 65.62 & [49.17-82.08] \\
\hline & $\begin{array}{l}\text { Kardjadj } \\
\text { et al. } 2015 \mathrm{~b}\end{array}$ & Algeria & Sheep & Blood & c-ELISA & 3336 & 362 & 10.85 & [9.80-11.91] \\
\hline & $\begin{array}{l}\text { Kardjadj } \\
\text { et al. } 2015 \mathrm{~b}\end{array}$ & Algeria & Goats & Blood & c-ELISA & 1216 & 214 & 17.59 & [15.46-19.74] \\
\hline & $\begin{array}{l}\text { Baazizi et al. } \\
2017\end{array}$ & Algeria & Sheep & Blood & c-ELISA & 2786 & 484 & 17.4 & [15.97-18.78] \\
\hline & $\begin{array}{l}\text { Baazizi et al. } \\
2017\end{array}$ & Algeria & Goats & Blood & c-ELISA & 610 & 152 & 24.9 & [21.49-28.35] \\
\hline \multirow[t]{6}{*}{ BTV } & $\begin{array}{l}\text { Madani et al. } \\
2011\end{array}$ & $\begin{array}{l}\text { Different } \\
\text { regions of } \\
\text { Algeria }\end{array}$ & Sheep & Blood & ELISA & 359 & 52 & 14.48 & [10.84-18.13] \\
\hline & $\begin{array}{l}\text { Madani } \\
\text { et al. } 2011\end{array}$ & $\begin{array}{l}\text { Different } \\
\text { regions of } \\
\text { Algeria }\end{array}$ & Goats & Blood & ELISA & 71 & 15 & 21.12 & [11.63-30.62] \\
\hline & $\begin{array}{l}\text { Madani et al. } \\
2011\end{array}$ & $\begin{array}{l}\text { Different } \\
\text { regions of } \\
\text { Algeria }\end{array}$ & Sheep & Blood & rt-PCR & 51 & 03 & 20 & {$[0.00-12.34]$} \\
\hline & $\begin{array}{l}\text { Madani et al. } \\
2011\end{array}$ & $\begin{array}{l}\text { Different } \\
\text { regions of } \\
\text { Algeria }\end{array}$ & Goats & Blood & rt-PCR & 15 & 00 & 00 & {$[0.00-0.00]$} \\
\hline & $\begin{array}{l}\text { Kardjadj } \\
\text { et al. } \\
\text { 2016a, } \\
\text { 2016b }\end{array}$ & $\begin{array}{l}\text { Different } \\
\text { regions of } \\
\text { Algeria }\end{array}$ & $\begin{array}{l}\text { Sheep and } \\
\text { goats }\end{array}$ & Blood & c-ELISA & 2421 & 138 & 5.70 & [4.78-6.62] \\
\hline & $\begin{array}{l}\text { Kouri et al. } \\
2018\end{array}$ & $\begin{array}{l}\text { The arid } \\
\text { zones of } \\
\text { Algeria }\end{array}$ & Goats & Blood & c-ELISA & 105 & 70 & 66.7 & [57.65-75.68] \\
\hline \multirow[t]{3}{*}{ BDV } & $\begin{array}{l}\text { Feknous } \\
\text { et al. } 2018\end{array}$ & $\begin{array}{l}\text { Different } \\
\text { regions of } \\
\text { Algeria }\end{array}$ & Sheep & Blood & Ag-ELISA & 689 & 00 & 00 & \\
\hline & $\begin{array}{l}\text { Feknous } \\
\text { et al. } 2018\end{array}$ & $\begin{array}{l}\text { Different } \\
\text { regions of } \\
\text { Algeria }\end{array}$ & Sheep & & $\mathrm{rt}-\mathrm{PCR}$ & 689 & 00 & 00 & \\
\hline & $\begin{array}{l}\text { Feknous } \\
\text { et al. } 2018\end{array}$ & $\begin{array}{l}\text { Different } \\
\text { regions of } \\
\text { Algeria }\end{array}$ & Sheep & Blood & Ab-ELISA & 576 & 344 & 60.17 & \\
\hline
\end{tabular}


Table 3 (continued)

\begin{tabular}{|c|c|c|c|c|c|c|c|c|c|}
\hline \multirow[t]{2}{*}{ Diseases } & \multirow[t]{2}{*}{ Reference } & \multirow[t]{2}{*}{ Region } & \multirow[t]{2}{*}{ Species } & \multirow[t]{2}{*}{ Sample type } & \multirow{2}{*}{$\begin{array}{l}\text { Lab diag- } \\
\text { nostic }\end{array}$} & \multirow[b]{2}{*}{ Sample size } & \multicolumn{2}{|c|}{ Individual level } & \multirow[b]{2}{*}{ CI (95\%) } \\
\hline & & & & & & & Positive case & $\begin{array}{l}\text { Prevalence } \\
\%\end{array}$ & \\
\hline & $\begin{array}{l}\text { Feknous } \\
\text { et al. } 2018\end{array}$ & $\begin{array}{l}\text { Different } \\
\text { regions of } \\
\text { Algeria }\end{array}$ & Sheep & & VNT & 197 & 144 & & \\
\hline CAEV & $\begin{array}{l}\text { Kouri et al. } \\
2018\end{array}$ & $\begin{array}{l}\text { The arid } \\
\text { zones of } \\
\text { Algeria }\end{array}$ & Goats & & i-ELISA & 105 & 00 & 00 & \\
\hline BVDV & $\begin{array}{l}\text { Feknous } \\
\text { et al. } 2018\end{array}$ & $\begin{array}{l}\text { Different } \\
\text { regions of } \\
\text { Algeria }\end{array}$ & Sheep & & VNT & 197 & 02 & & \\
\hline
\end{tabular}

$P P R V$ pest des petits ruminants virus, $B T V$ bluetongue virus, $B D V$ border disease virus, $C A E V$ caprine arthritis encephalitis virus, $B V D V$ bovine viral diarrhea virus, $i$-ELISA indirect enzyme-linked immunosorbent assays, $c$-ELISA enzyme-linked immunosorbent assay competitive, $V N T$ virus neutralization test, $r t-P C R$ real-time polymerase chain reaction

Bluetongue virus (BTV) There were three papers published on BTV prevalence among small ruminants. The total number of sheep and goat samples was 3022. Prevalence levels ranged from 5.70 to $66.7 \%$. The serotype identified was BTV-1. The overall estimated prevalence in sheep and goats was respectively, $13.41 \%$ (55/410) $(10.12-16.71 \%$; 95\% CI) and $44.50 \%(85 / 191)(37.45-51.55 \%$; 95\% CI).

Risk factor analysis indicated that grazing system, mixed flocks, presence of wetlands nearby the flocks, and lack of Culicoides control strategies were the major risk factors associated with bluetongue seropositivity in Algerian small ruminants (Kardjadj et al. 2016a, 2016b).

Border disease virus (BDV) Information on border disease virus in sheep was obtained from one study only using four (4) different test methods (Ag-ELISA, RT-PCR, AbELISA, and VNT). The total number of individual samples was 2151 . The overall estimated prevalence was $22.68 \%$ (488/2151) (20.92-24.46\%, 95\% CI).

Several risk factors were identified as linked to BDV such as climate, landscape, flock management and presence of goats and other diseases in the farm (Feknous et al. 2018).

Bovine viral diarrhea virus (BVDV-1 and BVDV-2) Prevalence of anti-BVDV antibody in sheep was obtained from one study only which was performing by VNT. The total number of individual samples was 197 and the prevalence was $1.01 \%$ (Feknous et al. 2018).

Caprine arthritis encephalitis virus (CAEV) One study was obtained about CAEV seroprevalence using i-ELISA method. The study was conducted on 105 goats which were all free of CAEV (Kouri et al. 2018).

\section{Parasitic causes}

Parasitic causes have been reported in six papers that have concerned only toxoplasmosis (Table 4). There are no data available on other parasitic causes that may induce abortion in small ruminants such as Neospora caninum and Trichomonas feetus.

Information on Toxoplasma gondii infection in small ruminant was obtained from 6 different studies. Four studies performing ELISA; one study performing IFAT; one study performing LAT; one study performing PCR; and one study performing histological technique. The total number of individual samples was 3938 sheep and 1042 goats. T. gondii infection prevalence among sheep and goats was $21.43 \%(844 / 3938)(20.15-22.71 \%, 95 \%$ CI) and $32.31 \%$ (337/1043) (29.47-35.15\% ; 95\% CI) respectively.

The main risk factors associated with toxoplasma infection were age, sex, region, season management system (herd size, presence of goats in sheep flocks) (Dechicha et al. 2015; Dahmani et al. 2018; Benlakehal et al. 2019; Mohamed-Cherif et al. 2019; Ait Issaad et al. 2020), and reproductive disorders (abortion stage, and flocks with a history of abortion) (Benlakehal et al. 2019; Dahmane et al. 2020; Ait Issaad et al. 2020). 


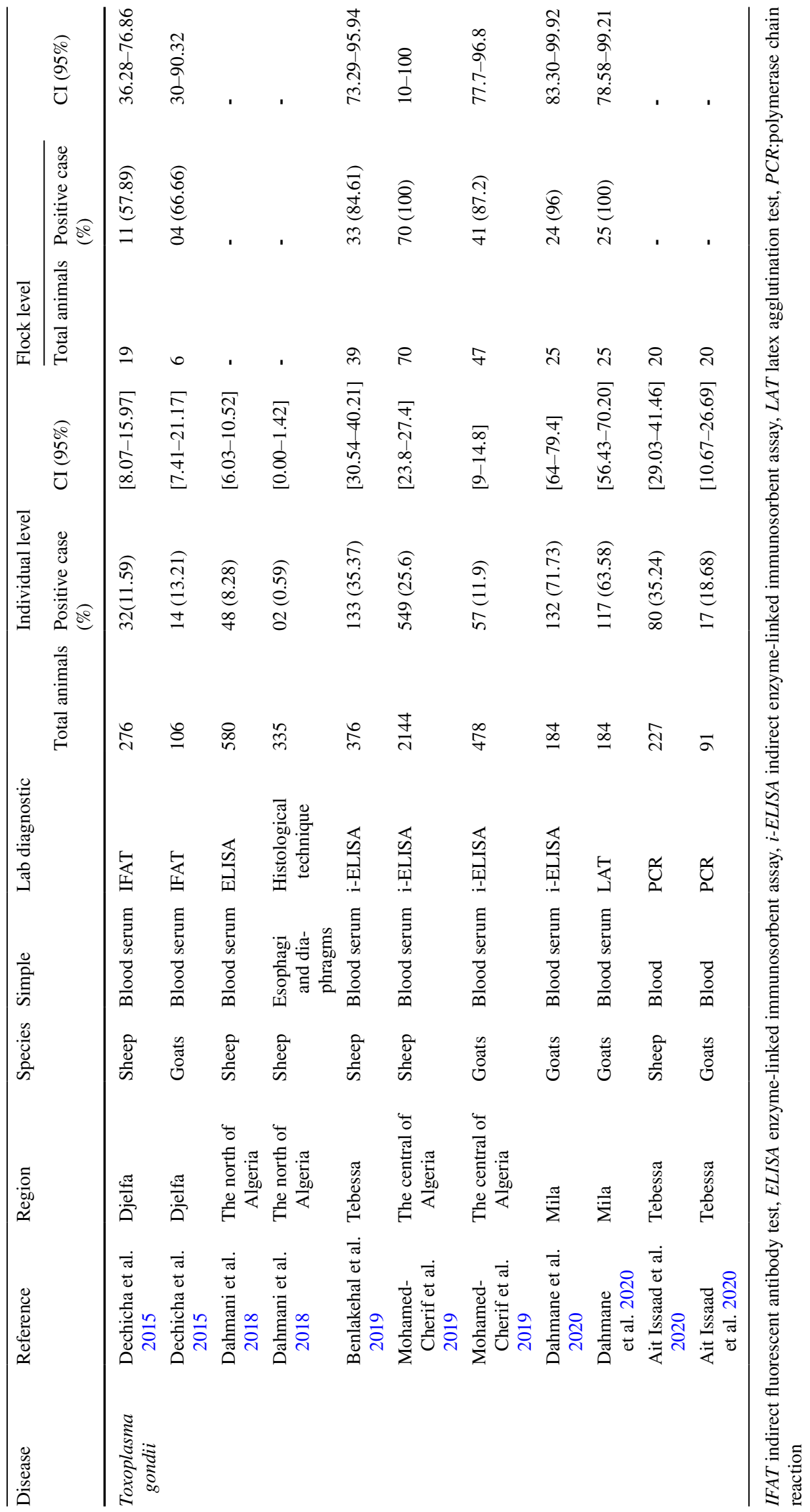




\section{Discussion}

Abortion in small ruminants can be caused by a variety of infectious and non-infectious agents. It can cause great economic losses (Givens and Marley 2008; Holler 2012). Despite preventive recommendations made by veterinarians of the State for several years, abortion in small ruminants remains a difficult problem in Algeria. The first publication on the causes of abortions in small ruminants in Algeria was published in 2003 which concerned brucellosis (Aggad 2003) and since then no study has been carried out until 2009 when a study on the same pathology was published (Bachir Pacha et al. 2009).

To the best of our knowledge, this systematic review is the first in Algeria which provides a comprehensive concept regarding the etiology of abortions in small ruminants through the pooling of data from studies published from the beginning in 2003 to 2020 . A total of 25 studies were eligible for this review which included a number of 54,330 small ruminants of which 5080 were revealed positive $(9.35 \%)$. The review indicates that there was very little research on abortive infectious and parasitic diseases of sheep and goats until 2011 when a marked increase in prevalence studies was noted.

The prevalence of different abortion diseases varies according to the studies. This difference could be attributed to several factors, the most important of which are difference in sampling technique, herd management, and the climate and diagnostic test used (Selim et al. 2018a; Tesfaye et al. 2020; Mamlouk et al. 2020).

Chlamydia and Q fever were observed in $32.72 \%$ and $20.62 \%$ of small ruminants, respectively. The prevalence of peste des petits ruminants was $15.76 \%$ and the overall prevalence of bluetongue in sheep and goats was, respectively, $13.41 \%$ and $44.50 \%$. Toxoplasma gondii infection prevalence among sheep and goats was $21.43 \%$ and $32.31 \%$ respectively. Border disease and bovine viral diarrhea were detected in $22.68 \%$ and $1.01 \%$ of sheep examined, respectively. The overall prevalence of brucellosis was $0.39 \%$ in sheep and $5.31 \%$ in goats. All samples were found to be free of salmonellosis and Caprine arthritis encephalitis virus (CAEV).

Chlamydia abortus, causing enzootic abortion in sheep, is considered one of the major causes of abortion in small ruminants worldwide (Tejedor-Junco et al. 2019). Abortion is observed in particular during the last 2 or 3 weeks of gestation (Arif et al. 2020). The prevalence reported herein ranges from 08.5 to $35.41 \%$ with an average of $32.72 \%$, which is in agreement with the previous prevalence of $27.2 \%$ in Morocco (Benkirane et al. 2015), 14.9\% in Egypt (Selim et al. 2018a), 21.8\% in Jordan (Al-Qudah et al. 2014), and 21.5\% in Brazil (Pinheiro Junior et al. 2010). It is higher than that reported in other studies in Tunisia: 1.9\% (Rekiki et al. 2005), 6.6\% (Mamlouk et al. 2020), and 3.2\% (Elandalousi et al. 2015).

The prevalence of Border disease virus (BDV) revealed herein is lower than reported elsewhere (Valdazo-Gonzalez et al., 2006; Krametter-Froetscher et al. 2010; Martin et al. 2015; Mishra et al. 2016). There are significant regional variations in the prevalence of the disease in small ruminants which are attributed to the levels of movement, regional differences in management practices, and herd density (Nettleton et al. 1992).

Toxoplasmosis, due to Toxoplasma gondii, is one of the major parasitic causes of reproductive failure associated with abortion, in sheep and goats (Weiss and Dubey 2009). The prevalence of toxoplasma-infection in small ruminants depends on the density of infected cats around the farm, the breeding conditions, the climate, the diagnostic technique used, and the sampling procedure (Liu et al. 2015; Hanif and Tasawar 2016; Tegegne et al. 2016). The reported prevalence in sheep (21.43\%) is comparable to those previously recorded in Morocco (20.8\%) (Benkirane et al. 2015) and Tunisia (19\%) (Gharbi et al. 2013), but higher than those reported in Pakistan (11.1\%) (Ramzan et al. 2009) and northeast China (3.0\%) (Wang et al. 2011). Higher values were observed in Tunisia (40.2\%) ( Lachkhem and Sakly 2015), Egypt (52.7\%) (Ibrahim et al. 2017), and Morocco (27.6\%) (Sawadogo et al. 2005). In goats, prevalence of $T$. gondii infection observed in this study was close to that recorded in Tunisia (34\%) (Lachkhem and Sakly 2015), and higher than that observed in Morocco (8.5\%) (Benkirane et al. 2015), Pakistan (11.2\%) (Ramzan et al. 2009), and central Ethiopia (11.6\%) (Bekele and Kasali 1989). Other reports have shown higher prevalences than ours, such as those from Pakistan (41.8\%) (Ahmed et al. 2016), Egypt (44.3\%) (Shaapan et al. 2010), and southern Ethiopia (55.18\%) (Tegegne et al. 2016).

Coxiella burnetii, is an obligate intracellular bacterium, which causes $\mathrm{Q}$ fever disease responsible for reproductive disorders such as abortion in ruminants (Elhaig et al. 2018). According to published data, the prevalence of $Q$ fever in sheep and goats in Algeria was $20.62 \%$, which is in agreement with $22.7 \%$ in Egypt (Selim et al. 2018b) and inferior to the results of Kalender (2001) who reported a prevalence of $38.59 \%$ in Turkey. Low results were recorded by Kilic and Kalender (2016) in Turkey (16\% in aborted ewes and $7.6 \%$ in non-aborted ewes).

Bluetongue is an infectious viral disease of domestic and wild ruminants. It is transmitted between ruminants by the bite of Culicoides midge vectors (Breard et al. 2004; Kaufmann et al. 2012). In the present study, the prevalence of BTV was $13.41 \%$ in sheep which is lower than the reported prevalence of $39.4 \%$ in Thailand (Apiwatnakorn 
et al. 1996) and 90\% in Turkey (Taylor et Mellor 1994) and higher than $6.57 \%$ in southeastern Iran (Mozaffari and Khalili 2012). The prevalence of BTV herein was $44.50 \%$ in goats which is lower than the reported prevalence of $73.0 \%$ in Thailand (Apiwatnakorn et al. 1996) and higher than the result of 3.9\% in Brazile (Mota et al. 2011).

Peste des petits ruminants (PPR), is a highly contagious viral disease of small ruminants in many countries in Africa, the Middle East, and Asia. It has been reported by FAO and OIE as a class one disease to be eradicated (OIE and FAO, 2015). In Algeria, PPR has been reported only in sheep with a prevalence of $14.05 \%$, which is significantly lower than other studies (Dhar et al. 2002; Ozkul et al. 2002; Khan et al. 2011 in Pakistan).

Bovine viral diarrhea virus (BVDV-1 and BVDV-2) has been identified in Algeria in sheep with a low prevalence $(1.01 \%)$ which is much lower than the results of other studies (O’Neill et al. 2004; Valdazo-Gonzalez et al. 2006; Gaffuri et al. 2006).

Brucellosis is an important zoonosis that causes massive economic losses in small ruminant farming with great public health significance. In sheep and goats, it is mainly caused by Brucella melitensis of which the main symptom is abortion (Celli and Gorvel 2004). In Algeria, the prevalence revealed in this systematic review and meta-analysis in goats and sheep was $5.32 \%$ and $0.39 \%$ respectively, which is largely lower than reported elsewhere (Mrunalini et al. 2000 and Singh et al. 2000 performed in India; Al-Dabagh et al. 2014 and Tamadhir et al. 2020 performed in Iraq).

\section{Conclusion}

This meta-analysis is the first synthesis study on abortive diseases in small ruminants in Algeria. It provides important information that could be useful in managing and monitoring programs to control abortive diseases in small ruminants. The main abortive diseases in small ruminants in Algeria are brucellosis, chlamydiosis, Q fever, salmonellosis, PPR, bluetongue, border disease, CAE, BVDV, and toxoplasmosis. Considering that some of these diseases are zoonoses, farmers must take important hygienic precautionary measures. Further research and surveillance will be needed to reduce the prevalence of these infections and, consequently, reduce economic damage and public health risks in Algeria.

Author contributions All authors read and approved the final manuscript.

Data availability All data generated or analyzed during this study are included in this published article.

\section{Declarations}

Ethics approval Not applicable.

Conflict of interest The authors declare that they have no competing interests.

\section{References}

Abdelkadir, K., Khatima, A. O., and Djamel, K., 2017. Seroprevalence of chlamydial abortion and Q fever in ewes aborted in the North-West of Algeria. Journal of Veterinary Medicine and Animal Health, 9(9), 246-249. https://doi.org/10.5897/JVMAH 2016.0474

Aggad, H., 2003. Serological studies of animal brucellosis in Algeria. Assiut Veterinary Medical Journal. 49(98), 121-130.

Ahmed, H., Malik, A., Arshad, M., Mustafa, I., Khan, M.R., Afzal, M.S., Ali, S., Mobeen, M., and Simsek S., 2016. Seroprevalence and spatial distribution of toxoplasmosis in sheep and goats in North-Eastern Region of Pakistan. Korean Journal of Parasitology. 54:439. https://doi.org/10.3347/kjp.2016.54.4.439

Ait Issaad, N., Abdelouahed, K., Bekhouche, S., Boubeuker, R., Adjemi, H.,Ouchene-Khelifi, NA., Ouchene. N., Oudhia, K., and Khelef, D., 2020. Molecular detection of the B1 gene of Toxoplasma gondii in blood samples of female sheep and goats in Tebessa, northeastern Algeria. Comparative Immunology, Microbiology and Infectious Diseases, 72,101530. https://doi. org/10.1016/j.cimid.2020.101530

Al-Dabagh, I.I., Jasim, B.M., and Jarjees, M.T., 2014. Seroprevalence of antibodies to toxoplasmosis, brucellosis and chlamydiosis in abortive sheep in Nineveh governorate, Iraq. Iraqi Journal of Veterinary Sciences. 28, 1, (21-25)

Al-Qudah, K., Sharif, L., Raouf, R., Hailat, N., and Al-Domy, F., 2004. Seroprevalence of antibodies to Chlamydophila abortus shown in Awassi sheep and local goats in Jordan Veterinarni Medicina-UZPI (Czech Republic), Veterinární Medicína; Prague Vol. 49, $\mathrm{N}^{\circ}$ 12,(2004): 460-466. DOI:10.17221/5740-VETMED

Apiwatnakorn, B., Bura, P., Pasavorakul, O., 1996. Serological study for bluetongue in Thailand. In: George TD, Kagao P, editors. First Southeast Asia and pacific regional bluetongue symposium. Kunming, P. R. China: pp. 20-22.

Arif E.D., Saeed N.M., and Rachid S.K., 2020. Isolation and identification of Chlamydia abortus from aborted ewes in Sulaimani Province, Northern Iraq. Pol. Journal of Microbiology. 69 (1), 65

Lachkhem, I.L., and Sakly, D.S., 2015. Prevalence of Toxoplasmosis in Sheep, Goats and Cattle in Southern Tunisia. Journal of Bacteriology and Parasitology. 6:5. https://doi.org/10.4172/ 2155-9597.1000245.

Baazizi, R., Khelef, D., and Hussain, T., 2017.Peste des petits ruminants in Algeria: Viral circulation of PPRV between 2012 and 2015. Journal of Animal and Plant Science. 27(5): 15221527.https://doi.org/10.1371/journal.pone.0175461

Bachir-Pacha, M., Kechih, S., Berber, A and Triki-Yamani, R.R., 2009. An Inquiry about ruminants' epidemiologic brucellosis in some Algerian departments, Bulletin UASVM Veterinary Medicine, 66, 370-375. https://doi.org/10.15835/buasvmen-vm:66:2:4243

Bekele, T., and Kasali, O.B., 1989. Toxoplasmosis in sheep, goats and cattle in central Ethiopia. Veterinary Research. Commun. 13:371-375. https://doi.org/10.1007/BF00346069.

Benkirane, A., Essamkaoui, S., El Idrissi, A., Lucchese, L., and Natale, A., 2015. A serosurvey of major infectious causes of abortion in small ruminants in Morocco. Veterinaria Italiana. 51:25-30. 
Benlakehal, A., Miroud, K., Djeghim, H., and Kaidi, R., 2019. Serological survey for antiToxoplasma gondii antibodies in sheep of northeastern Algeria. Tropical Animal Health and Production, 51(8), 2227-2233. https://doi.org/10.1007/s11250-019-01921-2

Breard, E., Hamblin, C., Hammoumi, S., Sailleau, C., Dauphin, G., and Zientara, S., 2004. The epidemiology and diagnosis of bluetongue with particular reference to Corsica. Research Veterinary Science. 77:1-8.

Celli, J., and Gorvel, J.P., 2004. Organelle robbery: Brucella interactions with the endoplasmic reticulum. Current Opinion in Microbiology. 7 (1): 93-97.

Dahmane, A., Boussena, S., Hafsi, F., and Ghalmi, F., 2020. Serological Survey and Associated Risk Factors on Toxoplasma gondii Infection in Goats in Mila District, Algeria. Folia Veterinaria, 64(1), 48-59.https://doi.org/10.2478/fv-2020-0007

Dahmani, A., Harhoura, K., Aissi, M., Zenia, S., Hamriouri, B., Guechi, N., Ait Athmane, M., and Kadour, R., 2018. The zoonotic protozoan of sheep carcasses in the north of Algeria: A case of ovine toxoplasmosis. Journal of the Hellenic Veterinary Medical Society, 69(2),1004-1012. https://doi.org/10. 12681/jhvms. 18385

De Nardi,, M., Saleh S.M.L., Batten C., Oura C., Di Nardo A., and Rossi D., 2012. First Evidence ofPeste des Petits Ruminants (PPR) Virus Circulation in Algeria (Sahrawi Territories): Outbreak Investigation and Virus Lineage Identification. Trans bound and Emer. Disease. 59(3): 214-222. https://doi.org/10. 1111/j.1865-1682.2011.01260.x

Dechicha, A.S., Bachi, F., Gharbi, I., Gourbdji, E., Baazize-Ammi, D., Brahim-Errahmani, M., and Guetarni, D., 2015. Sero-epidemiological survey on toxoplasmosis in cattle, sheep and goats in Algeria. African Journal of Agricultural Research, 10(20), 2113-2119. https://doi.org/10.5897/AJAR2015.9575

Dhar, P., Sreenivasa, B., Barrett, T., Corteyn, M., Singh, R. and Bandyopadhyay, S., 2002. Recent epidemiology of Peste des petits ruminant virus (PPRV). Veterinary Microbiology. 88: 153-159. https://doi.org/10.1016/S0378-1135(02)00102-5

Elandalousi, R., Ghram, A., Maaroufi, A., and Mnif, W., 2015. Séroprévalence des maladies abortives zoonotiques chez les ruminants au nord de la Tunisie, Research. 2, 1419.

Elhaig, M.M., Selim, A., Mandour, A.S., Schulz C., and Hoffmann B., 2018. Prevalence and molecular characterization of peste des petits ruminants virus from Ismailia and Suez, Northeastern Egypt, 2014-2016, Small ruminant Research. 169, 94-98. https://doi.org/10.1016/j.smallrumres.2018.07.001

Entrican G, Wattegedera S, Rocchi M, Wheelhouse N, 2009. Pregnancy, indoleamine 2,3-dioxygenase (IDO) and chlamydial abortion: An unresolved paradox, Veterinary Microbiology, Volume 135, Issues 1-2, 2009, P 98-102. https://doi.org/10. 1016/j.vetmic.2008.09.028.

Feknous, N., Hanon, JB., Tignon, M, Khaled, H and Bouyoucef, A., 2018. Seroprevalence of border disease virus and other pestiviruses in sheep in Algeria and associated risk factors. BMC Veterinary Research. 14(1):339.https://doi.org/10.1186/ s12917-018-1666-y

Gabli, A., Agabou, A. and Gabli, Z., 2015. Brucellosis in nomadic pastoralists and their goats in two provinces of the eastern Algerian high plateaus. Tropical Animal Health and Production. 47, 1043-1048. https://doi.org/10.1007/s11250-015-0825-4

Gaffuri, A., Giacometti, M., Tranguillo, V.M., Magnino, S., Cordioli, P., Lanfranchi, P., 2006. Serosurvey of roe deer, chamois and domestic sheep in the Central Italian Alps. Journal of Wildlife Disease, 42, 685-690.

Gharbi M., Zribi L., Jedidi M., Chakkhari H., Hamdi S., R'hayem S., Zribi N., Souli M., and Darghouth, M.A., 2013. Prévalence d'infection des ovins par Toxoplasma gondii en Tunisie.
Bulletin de la Société de Pathologie Exotique. 106:184-187. https://doi.org/10.1007/s13149-013-0290-4.

Givens, M. D., \& Marley, M. S. D. 2008. Infectious causes of embryonic and fetal mortality. Theriogenology, 70(3), 270-285.

Hanif, M., and Tasawar Z., 2016. Seroprevalence and riskfactorsassociatedwithtoxoplasmosis in sheep in Multan and Khanewal districts of Punjab (Pakistan), Journal of Animal Plant Science. 26 (6) 1620-1627.

Hanif, M., Tasawar, Z. 2016. Hematological and Serum Biochemical Changes in Sheep Naturally Infected with Toxoplasma gondii in Southern Punjab (Pakistan)., Pakistan Journal of Life \& Social Sciences. 14(1), 52-56.

Hireche, S., Bouaziz, O., Djennad, D., Boussen, S., Imgur, R., Kabouia, R., and Bererhi, E., 2014. Seroprevalence and risk factors associated with Chlamydophila spp. infection in ewes in the northeast of Algeria. Tropical Animal Health and Production. 46:476-473. https://doi.org/10.1007/s11250-013-0515-Z

Hireche, S., Ababneh, M.M.K., Bouaziz, O. et al. 2016. Seroprevalence and molecular characterization of Chlamydia abortus in frozen fetal and placental tissues of aborting ewes in northeastern Algeria. Trop Anim Health Prod 48, 255-262. https://doi.org/10.1007/ s11250-015-0944-y

Holler, L. D. 2012. Ruminant abortion diagnostics. Veterinary Clinics of North America-Food Animal Practice, 28(3), 407.

Ibrahim, H.M., Mohamed, A.H., El-Sharaawy, A.A., and El-Shqanqery, H.E., 2017. Molecular and serological prevalence of Toxoplasma gondii in pregnant women and sheep in Egypt. Asian Pac. Journal of Tropical Medecine. 10:996-1001. https://doi.org/10.1016/j. apjtm.2017.09.012.

Kalender, H., 2001. The incidence of Coxiella burnetii infection in ewes in Elaziğ and neighbouring provinces. Turkish Journal of Veterinary and Animal Science. 25:51-55.

Karaca, M, Babur, C, Celebi, B, Akkan, H A, Tutuncu, M, Keles, I, Uslu, B A, and Kilic, S., 2007. Investigations on seroprevalence of toxoplasmosis, listeriosis and brucellosis in goats living in the region of Van, Turkey. YYU Fac Derg. 18:45-49.

Kardjadj, M., Ben-Mahdi, M.H., and Pam, D.L., 2015a. First serological and molecular evidence of PPRV occurrence in Ghardaïa district, center of Algeria. Tropical Animal Health and Production. https://doi.org/10.1007/s11250-015-0860-1.

Kardjadj, M., Metref, D., Kouidri, B., Luka, P.D., Ben-Mahdi, M.H., 2015b. Seroprevalence distribution and risk factor for Peste des Petits Ruminants (PPR) in Algeria. Preventive Veterinary Medecine. .https://doi.org/10.1016/j.prevetmed.2015.09.002

Kardjadj, M., Kouidri, B., Metref, D., Luka, P.D. and Ben-Mahdi M.H., 2016a. Abortion and various associated risk factors in small ruminants in Algeria. Prev. Vet. Med., 123, 97 101. https://doi.org/10. 1016/j.prevetmed.2015.11.015

Kardjadj, M., Luka, P.D. and Ben-Mahdi, M.H., 2016b. Sero-epidemiology of bluetongue in Algerian ruminants. African Journal of Biotechnology. 15 (20), 868-871. https://doi.org/10.5897/AJB20 16.15343

Kardjadj, M., 2017. An epidemiological overview of small ruminant diseases in Algeria. Rev Sci Tech OIE, 36, pp.997-1006. https:// doi.org/10.20506/rst.36.3.2731

Kaufmann, C., Steinmann, I.C., Hegglin, D., Schaffner, F., Mathis, A., 2012. Spatio-temporal occurrence of Culicoides biting midges in the climatic regions of Switzerland, along with large scale species identification by MALDI-TOF mass spectrometry. Parasite and Vectors. 5:1-10.

Khaled, H., and Bouyoucef, A., 2013. Assessment of zoonotic risks associated with ruminant abortions for Algerian farmers. Bull. UASVM Vet. Med. 70 (2), 253-257. https://doi.org/10.15835/ buasvmcn-vm:70:2:9202 
Khaled, H., Sidi-Boumedine, H., Merdja, S., Dufour, P., Dahmani, A., Thiéry, R., Rousset, E., and Bouyoucef, A., 2016. Serological and molecular evidence of $\mathrm{Q}$ fever among small ruminant flocks in Algeria. Comparative Immunology Microbiology Infectious Disease. 47:19-25. https://doi.org/10.1016/j.cimid.2016.05.002

Khan, H.A., Rahman, S., Khan, A. and Khan, Q.M., 2011. Detection and sequencing of field isolates of Pest Des Petits Ruminant virus from Punjab province, Pakistan. Pakistan Journal of Life Science. 11: $212-217$.

Kilic, A., and Kalender, H., 2016. A study of the correlation between Coxiella burnetii seropositivity and abortions in sheep in Eastern and Southeastern Turkey. Indian Journal of Animal Research. 50: 401-405.

Kouri, A., Charallah, S., Kouri, F., Amirat, Z and Khammar, F., 2018. Reproductive performances and abortion etiologies of native Bedouin goats in the arid zones of Algeria. Livestock Research for Rural Development. 30, Article:127. http://www. 1rrd.org/lrrd30/7/schar30127

Krametter-Froetscher, R, Duenser, M, Preyler, B, Theiner, A, Benetka, V, Moestl, K, et al., 2010. Pestivirus infection in sheep and goats in West Austria. Veterinary Journal. 186:342-6.

Liu, Q., Wang, Z.D., Huang, S.Y., and Zhu, X.Q., 2015. Diagnosis of toxoplasmosis and typing of Toxoplasma gondii, Parasite and Vectors. 8, 292, 10.1186\%2Fs13071-015-0902-6

Madani, H., Casal, J., Alba, A., Allepuz, A., Cêtre-Sossah, C., Hafsi, L., and Napp, S., 2011. Animal Diseases Caused by Orbiviruses, Algeria. Emerging Infectious Disease. 17:2325-2327.https://doi. org/10.3201/eid1712.110928

MADR, Ministère de l'Agriculture et du Développement Rural, 2018. statistiques agricoles, madr.gov.dz.

Rondia P., 2006. Aperçu de l'élevage ovin en Afrique du Nord. Filière Ovine Caprine (18) : 11-14

Mamlouk, A., Guesmi K., Ouertani, I., Kalthoum, S., Selmi, R., Aicha, E.B., Mohamed, B.B.H., Gharbi, R., Lachtar, M., and Dhaouadi A., 2020. Seroprevalence and associated risk factors of Chlamydia abortus infection in ewes in Tunisia, Comparative Immunology and Microbiology and Infectious Diseases. Article 101500

Martin, C, Duquesne, V, Adam, G, Belleau, E, Gauthier, D, and Champion, JL, 2015. Pestiviruses infections at the wild and domestic ruminants interface in the French southern Alps. Veterinary Microbiology. 175:341-8.

Mrunalini, N., Sastry, P.R., Pandarinadh, G.N., 2000. Control of brucellosis epidemic in goats in a farm." Indian Veterinary Journal. 77, $11:$ : 932-935.

Mebirouk-Boudechiche, L., Boudechiche, L., Ferhat, R., and Tahar, A., 2014. Relation entre disponibilité en herbe, ingestion et activité de béliers au pâturage. Archivos de Zootecnia. 63 (242) : 277-287, doi : https://doi.org/10.4321/S0004-05922014000200006

Merdja, S. E., Khaled, H., Aaziz, R., Vorimore, F., Bertin, C., Dahmani, A., and Laroucau, K., 2015a. Detection and genotyping of Chlamydia species responsible for reproductive disorders in Algerian small ruminants. Tropical Animal Health and Production, 47(2), 437-443. https://doi.org/10.1007/s11250-014-0743-x

Merdja, S-E., Khalid, H., Dahmani, A., and Bouyoucef, A., 2015b. Chlamydial abortion in Algerian small ruminants. Bulletin of University of Agricultural Sciences and Veterinary Medicine Cluj-Napoca. 72(1):23-26. https://doi.org/10.15835/buasvmenvm: 10283

Mishra, N, Rajukumara, K, Vilcek, S, Kalaiyarasua, S, Beheraa, SP, and Dubeya, P, 2016. Identification and molecular characterization of border disease virus (BDV) from sheep in India. Comparative Immunology and Microbiology Infectious Diseases. 44:1-7

Mohamed-Cherif, A., Miroud, K., Benfodil, K., Ansel, S., Khelef, D., Kaidi, D., and AitOudhia, K., 2019. Cross Sectional Survey on Toxoplasma gondii Infection in Cattle, Sheep, and Goats in
Algeria: Seroprevalence and Risk Factors. Veterinary Science. 6 (3) 63. https://doi.org/10.3390/vetsci6030063

Moher, D., Liberati, A., Tetzlaff, J., Altman, D.G., and PRISMA Group. 2009. Preferred reporting items for systematic reviews and meta-analyses: the PRISMA statement. PLoS Medicine, 6, e1000097. https://doi.org/10.1371/journal.pmed.1000097

Mota, I.O.; Castro, R.S.; Alencar, S.P.; Lobato, Z.I.P.; Lima Filho, C.D.F.; Araújo Silva, T.L.; Dutra, A.C.T.; and Nascimento, S.A., 2011. Anticorpos contra o vírus do grupo da língua azul em caprinos e ovinos do sertão de Pernambuco e inferência sobre sua epidemiologia em regiões semiáridas. Arquivo Brasileiro de Medicina Veterinária e Zootecnia, Belo Horizonte. 63, 6, 15951598. https://doi.org/10.1590/S0102-09352011000600045

Mozaffari, A., and Khalili, M., 2012.The first survey for antibody against bluetongue virus in sheep flocks in southeast of Iran. Asian Pacific Journal of Tropical Biomedicine. S1808- S1810.

Nettleton, PF, Gilmour, JS, Herring, AJ, Sinclair, AJ., 1992. The production and survival of lambs persistently infected with border disease virus. Comparative Immunology and Microbiology Infectious Diseases. 15(3):179-88

Office of International Epizootics and Food and Agriculture Organization, 2015. Global strategy for control and eradication of PPR. FAO and OIE International conference for the control and eradication of Peste des petits ruminants (PPR). Abidjan, Cote D. Ivoire. pp. $1-83$

O'Neill, R.G., O' Connor, M., and O' Reilly, P.J., 2004. A survey of antibodies to pestivirus in sheep in the Republic of Ireland. Irish Veterinary Journal, 57, 525-530.

Ouchene-Khelifi, N.A., Ouchene, N., Da Silva1, A. and Lafri, M., 2018. Multivariate characterization of phenotypic traits of Arabia, the main Algerian goat breed. Livestock Research for Rural Development. 30 (7)

Ouchene-Khelifi, N.A., Ouchene, N., Maftah, A., Da Silva, A.B., and Lafri, M., 2015. Assessing admixture by multivariate analyses of phenotypic differentiation in the Algerian goat livestock.Tropical Animal Health and Production. 16https://doi.org/10.1007/ s11250-015-0869-5

Ozkul, A., Akca, Y., Alkan, F., Barrett, T., Karaoglu, T., Dagalp, S.B. anderson, J., Yesilbag, K., Cokcaliskan, C., Gencay, A. and Burgu, I., 2002. Prevalence, distribution, and host range of peste des petits ruminant viruses. Turkey Emerging Infectious Diseases. 8: 708- 712. https://doi.org/10.3201/eid0807.010471

Pinheiro Junior, J.W., Mota, R.A., Piatti, R.M., Oliveira, A.A.d.F., Silva A.M.d., Abreu, S.R.d.O., G. Anderlini, A., Valença, R.M.B., 2010. Seroprevalence of antibodies to Chlamydophila abortus in ovine in the State of Alagoas, Brazil. Brazilian Journal of Microbiology., 41, 358-364

Ramzan, M., Akhtar, M., Muhammad, F., Hussain, I., HiszczyńskaSawicka, E., Haq, A.U., Mahmood, M.S., and Hafeez, M.A., 2009. Seroprevalence of Toxoplasma gondii in sheep and goats in Rahim Yar Khan (Punjab), Pakistan. Tropical Animal Health and Production. 41:1225. https://doi.org/10.1007/s11250-009-9304-0.

Rechidi-Sidhoum, N., Niar, A., Nemmiche, S. and Homrani, A. 2018. Serological diagnosis of brucellosis at the ruminants in Mostaganem (Algeria). International Journal Bioscience. 12(5): 271278..https://doi.org/10.12692/ijb/12.5.271-278

Rekiki, A., Thabti, F., Dlissi, I., Russo, P., Sanchis, R., Pepin, M., Rodolakis, A., and Hammami, S., 2005. Seroprevalence survey of major infectious abortive diseases in small ruminants in Tunisia, Revue de Médecine Vétérinaire. 156 (7) 395-401.

Sawadogo, P., Hafid, J., Bellete, B., Sung, R.T.M., Chakdi, M., Flori, P., Raberin, H., Hamouni, I.B., Chait, A., Dalal, A., 2005. Seroprevalence of $T$. gondii in sheep from Marrakech, Morocco. Veterinary Parasitology. 130:89-92. https://doi.org/10.1016/j.vetpar. 2005.03.025. 
Selim, A., Elhaig, M., Moawed, S., 2018a. A Serological Survey of Four Abortifacient Infectious Agents among Small Ruminant in Egypt. Asian Journal of Animal Veterinary Advances. 13 (2), 114-121

Selim, A., Yang, E., Rousset, E., Thiéry, R., Sidi-Boumedine, K., 2018b. Characterization of Coxiella burnetii strains from ruminants in a Galleria mellonella host-based model, New microbes and new infections. 24, 8-13. https://doi.org/10.1016/j.nmni.2018. 02.008

Shaapan, R.M., Hassanain, M.A., Khalil, F.A.M., 2010. Modified Agglutination Test for Serologic Survey of Toxoplasma gondii Infection in Goats and Water Buffaloes in Egypt. Research Journal of Parasitology. 5:13-17.

Singh, S.V, Agarwal, G.S, Batra, H.V, Gupta, V.K, Singh N., 2000. Monitoring of Brucella infection associated with reproductive losses using multiple serological tests in organized goat and sheep flocks. Indian Journal of Animal Science. 70(2):154-156

Tamadhir, A., Al-Ahmed, A., Salman Sufian, S., 2020. seroprevalence of enzootic abortion and border disease in small ruminants in albasra province, IRAQ. Plant Archives. 20, 2, 2722-2727.

Taylor, W.P., and Mellor, P.S., 1994. Bluetongue virus distribution in Turkey 1978-1981. Epidemiology Infection. 112:623-633.

Tegegne, D., Kelifa, A., Abdurahaman, M., and Yohannes, M., 2016. Seroepidemiology and associated risk factors of Toxoplasma gondii in sheep and goats in Southwestern Ethiopia, BMC Veterinary Research. 12, 280, https://doi.org/10.1186/2Fs12917-016-0906-2

Tejedor-Junco, M.T., González-Martín, M., Corbera, J.A., Santana, Á., Hernández, C.N., Gutiérrez, C., 2019. Preliminary evidence of the seroprevalence and risk factors associated with Chlamydia abortus infection in goats on the Canary Islands, Spain. Tropical Animal Health Production. 51 (1), 257-260

Tesfaye, A., Sahele, M., Sori, T., Guyassa, C., Garoma, A., 2020. Seroprevalence and associated risk factors for chlamydiosis, coxiellosis and brucellosis in sheep and goats in Borana pastoral area, southern Ethiopia. BMC Veterinary Research. 16, 1-8

Valdazo-Gonzalez, B., Alvarez-Martinez, M., and Greiser-Wilke, I., 2006. Genetic typing and prevalence of Border disease virus (BDV) in small ruminant flocks in Spain. Veterinary Microbiology, 117, 141-153. https://doi.org/10.1016/j.vetmic.2006.06.008

Vidić, B., Savić-Jevđenić, S., Grgić, Ž., Bugarski, D., Maljković, M., 2007. Infectious abortion in sheep. Biotechnology in Animal Husbandry. 23 (5-6), 383 - 389

Wang, C.R., Qiu, J.H., Gao, J.F., Liu, L.M., Wang, C., Liu, Q., Yan, C., and Zhu, X.Q., 2011. Seroprevalence of Toxoplasma gondii infection in sheep and goats in northeastern China. Small Ruminant Research. 97:130-133. https://doi.org/10.1016/j.smallrumres. 2011.02.009.

Weiss, L.M., and Dubey J.P., 2009. Toxoplasmosis: A history of clinical observations, International Journal of Parasitology. 39 (8) 895-901, https://doi.org/10.1016/j.ijpara.2009.02.004

Publisher's note Springer Nature remains neutral with regard to jurisdictional claims in published maps and institutional affiliations. 